\title{
Public Administration in an Atypical Transition and the Need for the Agents of Europeanisation in Kosovo
}

\author{
Remzije Istrefi \\ Arben Hajrullahu*
}

\author{
http://doi.org/10.31297/hkju.20.2.5 \\ UDK 35.07(4EU:497.115) \\ 342.97(4EU:497.115) \\ 341.176(4EU:497.115) \\ Review scientific paper / pregledni znanstveni rad \\ Received / primljeno: $\quad$ 20.12.2019. \\ Accepted / prihvaćeno: $\quad$ 8. 5. 2020.
}

This article explores public administration reform in Kosovo. Given that the main political discourse in the country after the 2008 Declaration of Independence has involved European integration, reform is directed at achieving European Union benchmarks and its governance values. The

Remzije Istrefi, Associate Professor, Faculty of Law, University of Prishtina, and Judge at the Constitutional Court of Kosovo, Pristina, Republic of Kosovo (izvanredna profesorica Pravnog fakulteta Sveučilišta u Prištini i sutkinja Ustavnog suda Kosova, Priština, Kosovo, e-mail: remzie.istrefi@uni-pr.edu). The views expressed here are given from a personal academic point of view and not in an official judicial capacity.

ORCID ID: https://orcid.org/0000-0002-8854-5907

** Arben Hajrullahu, Professor of Political Science, University of Prishtina, and Executive Director of the Centre for Political Courage, Pristina, Republic of Kosovo (professor Političkih znanosti na Sveučilištu u Prištini i izvršni direktor Centra za političku hrabrost, Priština, Kosovo, e-mail: arben.hajrullahu@uni-pr.edu)

ORCID ID: https://orcid.org/0000-0002-7435-435X. 
aim of this paper is threefold: to analyse how the atypical transition in Kosovo affects administrative and governance reforms, to examine the Europeanisation process and efforts to harmonise legislation with the European Union's acquis communautaire as the main driving force towards a successful transition, and to reiterate the relevance and function of the education system in the Europeanisation process. The article concludes by asking and debating the following question: can the Europeanisation process be accomplished successfully when the educational system, which is limited in scale, does not manage to generate a sufficient number of agents of Europeanisation?

Keywords: Europeanisation, EU, Kosovo, public administration, education, Europeanisation agents

\section{Introduction}

With the end of the communist regime in the 1990s, the former Yugoslav territories faced an atypical transition. Whereas other communist countries in Central, Eastern, and South-Eastern Europe initiated a democratic transition, the former Yugoslav territories faced violence on a mass scale, as well as political and economic decline. International intervention, including military force, enabled the former Yugoslav territories to progress towards a state administration aiming at good governance and economic reforms. Compared to other communist dictatorships, the nature of Yugoslav communism with its "self-management system" was somewhat more liberal and often referred to as "market socialism". This type of "market socialism" was practised in the sense that the power of the state was a power of concentration, whereas property was a decentralising power (Sartori, 1997, p. 412-414). The general crisis of the Yugoslav "self-managing economic system", which was driven by the exploitation of raw materials in Kosovo, was a decisive catalyst for the unrest and instability of the Yugoslav system in the 1980s. However, according to Offe, a stable liberal-democratic constitutional state "can only be expected if at the same time with democracy and capitalism also an institutionalized far-reaching social security is ensured." (Offe, 1994, p. 93). In the post-communist transformation discourse Offe's thesis appears to be crucial, in particular when considering reforms and asking how to establish state administrations based on the best practices 
of good governance and how to integrate the Western Balkan countries ${ }^{1}$ into bigger polities, e.g. the European Union (EU). To date, in the Western Balkan countries the social security measures necessary for the success of the transformation process have not been enforced on a consistent basis. As long as the Western Balkan countries are only partially able to fulfil one of the main tasks of the state, namely the "fair and just" management and distribution of resources in society, lasting state administration reforms and stabilisation will be characterised by fragility and exposure to the process of power gain and economic control driven by particular groups; i.e., autocratically-ruled political parties in their respective societies.

In the absence of social satisfaction, social stability cannot take hold and this could exacerbate ethnic tensions and economic decline. The lack of a middle class in the Western Balkan countries is omnipresent. A huge majority of the population face serious financial difficulties, as opposed to a small minority who in a very short time after 1989 boosted their wealth through illegal activities. This could lead to a brain drain process that might constrain economic and democratic transitions in these countries. The widespread absence of the middle class in the Western Balkans has political consequences as well. According to Parrott, "social structure and the content of political culture are related; witness the widely accepted proposition that the rise of middle class is a source of liberal democracy, and the more controversial notion that the working class is the main social basis of authoritarianism" (Parrott, 1997, p. 22).

Merkel and Schmitter distinguish between liberalisation, democratisation, and consolidation in the process of change from an authoritarian to a democratic system (Merkel, 1995b, p. 36). According to Schmitter, this depends on a set of endogenous and exogenous factors: how the process of successful change from an authoritarian to a democratic system develops, how long it lasts, and whether it can be successfully completed. Regarding the most important endogenous factors, the following questions are asked: Which pre-authoritarian democracy experiences can a country use? What character and duration of existence did the previous authoritarian system have? How did the old regime collapse; how long is the transition phase? What strategies are pursued by decision-making elites in the transition and consolidation phases and how are they perceived by the masses? (Schmitter, 1988, p. 93 in Merkel, 1995b, p. 36). The follow-

1 Former Yugoslav territories, minus Slovenia, plus Albania, namely: Albania, Bosnia and Herzegovina, Croatia, Kosovo, Montenegro, North Macedonia, and Serbia. Because Croatia is an EU member, the EU refers to the Western Balkan Six: WB6. 
ing three dimensions are important exogenous factors in systemic change processes: the democratic stability of neighbouring states, integration into supranational and international economic and political associations, and international support (Schmitter, 1985, p. 64 in Merkel, 1995b, p. 36).

The third and fourth wave of democratisation have produced extremely "fragile democracies" (Casper, 1995). The endogenous and exogenous factors identified by Schmitter are essential for the consolidation of the functioning constitutional state and integration processes (Merkel, 1995a, p. 5). However, Merkel speaks of a sequence of three interlocking phases in terms of democratic consolidation: structural consolidation (constitution, state organisation) influences, the level of representative consolidation (parties, associations), and the long-term process of civil-cultural consolidation. He notes that only when all three phases of consolidation have been successfully completed, it is possible to speak of a consolidated and crisis-resistant democracy. (Merkel, 1995b, p. 39). Without the successful accomplishment of all three interlocking phases, there is no perspective for a public administration based on the values and principles of good governance, transparency, and accountability within a rule-of-law-based system, nor for the "fair and just" distribution of resources in society.

In comparison to other states in the region and beyond, Kosovo has been undergoing the most atypical transition. This transition is characterised by a post-WWII communist dictatorship, Serbian apartheid-like discrimination in the 1990s, and the post-1999 United Nations Interim Administration in Kosovo (UNMIK). After roughly ten years of interim international administration and UN facilitated negotiations, Kosovo declared its independence in February 2008. Prior to the 1999 war, public administration under the Serbian regime was characterised by systematic and widespread ethnically-based human rights violations and offences.

Since 1999, the goal of both international and Kosovo agencies has been to build inclusive public administration institutions that can deliver fair and reliable public services to citizens and increase trust in public institutions. However, it remains to be seen if public administration has the capacity to implement fair and reliable public services to citizens and inspire trust in the public sector, given that existing challenges are a consequence of the past and continue to shape aspirations for EU membership.

This article undertakes an in-depth case study examination and draws on the following sources: academic studies (as we consider the applicability of theoretical considerations to public administration reforms and transformation processes in post-communist European countries), legal documents, reports by independent organisations, strategic and policy studies, as well as media 
sources. In addition, between March and December of 2019 the authors conducted several semi-structured interviews with scholars and officials in Kosovo and beyond. This introductory section is followed by an analysis of the Europeanisation process and the efforts to harmonise legislation with the EU's acquis communautaire ${ }^{2}$ as the main driving force towards a successful transition from a dictatorship to a functional democratic regime based on the rule of law and a functional public administration in the Western Balkan countries in general. The EU remains highly involved in the reform of public administration, as Kosovo has made a commitment in the policy dialogue to implement public administration reforms under the Stabilisation Association Agreement (SAA). The emphasis in this section will be on the role and function of education in the Europeanisation process and in enhancing the capacities of public administration to comply with the EU acquis. Because the Europeanisation process requires agents, this article also addresses the following question: how can Europeanisation and EU integration be accomplished successfully if the educational sector generates human capacities on a very limited scale? Consequently, the processes of reforming public administration in Kosovo as a part of EU integrative efforts offer an illustration of the need for the generation of Europeanisation agents by means of an enhanced education system. In this context, the term Europeanisation agents refers to public servants and people in general who are convinced and guided by the values and norms of liberal democratic life embedded in the idea of "Europe as a whole and free", and as an area in which the market economy, social justice, rule of law, and human rights and dignity form the basis of free states and societies guided by the EU motto "united in diversity".

\section{Opting for Europeanisation and the Harmonisation Process of Legislation with the EU Acquis in Kosovo}

The concept of Europeanisation is one of the most researched areas within EU integration studies. ${ }^{3}$ Europeanisation, including and beyond

${ }^{2}$ With the entrance into force of the Lisbon Treaty in 1 December 2009, "Union" replaced and succeeded the European Community. Therefore, a new term was introduced and is being used: "EU acquis or Union acquis" (EU, 2007b).

${ }^{3}$ Europeanisation is considered a highly complex phenomenon and has been researched through various approaches, methodological frameworks, and concepts. Some authors have based their research approach on the basic premises of the theory, explaining 
functional EU integration, refers to a multidimensional process of social transformation, involving simultaneously the integration of societies, the transnationalisation of states, and globalisation (Petritsch \& Solioz, 2012). Europeanisation as a concept may have different explanations. Olsen defines Europeanisation as a phenomenon with many faces and contextualises it in terms of the following five categories: (1) processes involving changes in territorial aspects or changes to the external borders of the EU due to enlargement policies; (2) processes of institutional change at the EU level, meaning that these institutions will enforce sanctions in the case of noncompliance with set rules; (3) a bottom-up approach that takes into consideration the role of national government systems in shaping EU norms; (4) exporting forms of political organisation that highlight relations with non-EU actors and their ability to export forms of political organisation; and (5) as a project that attempts to unify the EU as a stronger unit (2002).

For Grabbe (2011), Europeanisation presents "the impact of the EU accession process on national patterns of governance", whilst Goetz (2001) has linked the term with the anticipatory and anticipated effects of accession on national administrations. Europeanisation is also defined as "the emergence and development at the European level of distinct structures of governance, that is, of political, legal and social institutions associated with political problem solving that formalizes interactions among the actors, and of policy networks specializing in the creation of authoritative European rules" (Risse, Cowles \& Caporaso, 2001, p. 3). According to Radaelli, Europeanisation includes processes of construction, diffusion, and implementation of formal and informal rules, procedures, policy paradigms, styles, and shared beliefs and norms which are first defined and consolidated in the EU policy process and then incorporated into the logic of domestic discourse, identities, political structures, and public policies (Radaelli, 2003). The most parsimonious definition of Europeanisation is that of a process whereby "states adopt EU rules" (Radaelli, 2000). The EU and its integration processes remain central to defining the concept of Europeanisation despite scholarly opinions on the differences and similarities between Europeanisation and European integration

changes by analysing institutions in time sequences and with "path dependency" as the main concept (Bulmer, 2007). Some authors have turned their attention to political processes, with an emphasis on changes in informal institutions, such as norms, values, and identities (Bache \& Marshall, 2004), while other authors use more contemporary research approaches to the concept of Europeanisation (Bandov \& Kolman, 2018). 
(Hirschhausen \& Patel, 2010; Howell, 2002). The EU has introduced a systematic Europeanisation process for countries before they acquire EU membership. Put simply, Europeanisation for potential candidate countries includes processes whereby they will embrace EU standards and values and incorporate them into practice in order to achieve a level of society that behaves and acts in accordance with these standards and values. Europeanisation through EU integration is based on the same EU principles, rules, and procedures, but its impact and how it is carried out in practice vary from country to country (Anastasakis, 2005, p. 80). This means that joining the EU involves economic, institutional, and legal reforms and the degree of success of these reforms relies on the state's ability and willingness to change. Economic and institutional reforms in states that have integrative aspirations are usually initiated by harmonising domestic legislation with EU standards. Harmonisation of legislation is an undertaking to meet the Copenhagen criteria that require an administrative and institutional capacity to implement the EU acquis (EC, 2016b). Countries aspiring to EU membership must harmonise their national laws, regulations, and procedures with the EU acquis. This can increase the effectiveness of EU legal structures in domestic contexts. Previous experience has revealed that harmonisation of national legislation with the EU acquis is a challenging process for states obtaining EU membership. Effective implementation of the EU acquis requires an entire institutional structure and a system which involves capable human resources and genuine Europeanisation agents.

Since the fall of communist regimes, the Western Balkan countries have become involved with the Europeanisation process in varying ways. The EU's strategy towards the Western Balkans has been shaped as response to emerging crises, marked by ad boc actions for stabilisation towards membership (Uvalic, 2010). Because of continuous political instability in the region in the 1990s, the EU initially failed to elaborate a clear, comprehensive, and long-term strategy for the Western Balkan countries. A fundamental change in EU and international strategies towards the Western Balkans took place after Kosovo conflict ended (Uvalic, 2010). With the adoption of the Declaration of Stability Pact for South Eastern Europe (1999), and European Council's (EC)'s announcement of a new approach towards the Western Balkan countries - the Stabilisation and Association Process (SAP) - as a way to support their transition and stabilisation, the prospects of future EU membership increased (Finnish Presidency and the EC, 1999). The EU strategy towards the Western Balkans was reinforced at the Thessaloniki Summit in June 2003 and by the Thes- 
saloniki Declaration, which affirmed that the future of the Balkans was within the EU (EC, 2004; EU-Western Balkans Thessaloniki Summit, 2003). In July 2006, the European Council established the Instrument for Pre-Accession Assistance (IPA), which replaced all previous financial assistance instruments available to the Western Balkan countries. IPA offers support for the following five main components: transition assistance and institution building, cross-border cooperation, regional development, human resources development, and rural development. In order to improve the quality of the EU-WB accession process, various other instruments have been used, such as the impact assessment of accession in key policy areas, estimates of budgetary implications of specific measures, and evaluation of a country's administrative capacity. The enlargement perspective for enhanced EU engagement with the Western Balkans has been restated by EU officials in declarations and statements where the specific challenges that the Western Balkans face have been recognised and the need for fundamental reforms and good neighbourly relations has been reiterated (EC, 2018). However, EU conditionality in the Western Balkans has been much stricter than in Central and Eastern Europe and this has had negative consequences for the internal political and economic processes of transition (Uvalic, 2009).

For the Western Balkans, Europeanisation means adjustment to advanced Western models as well as security and prosperity for the future (Anastasakis, 2005, p. 80). It has been stated that the process of preparing to join the EU empowers progressive forces in countries and creates space for domestically-driven reform movements to transform the way politics, economies, and societies work (Vogel, 2018). The processes of Europeanisation in their respective countries have also empowered Western Balkan reformists and moderates over nationalist forces to introduce domestic change (Börzel, 2011). Despite all the challenges, EU integration has become a political priority for all Western Balkan countries, leading to the adoption of EU resolutions, national strategies of EU integration, and other important documents (Uvalic, 2010).

At the present time, Western Balkan countries are at different stages of the EU integration process. They have all signed an SAA, though at very different times: Republic of North Macedonia in April 2001, Albania in June 2006, Montenegro in October 2007, Serbia in April 2008, Bosnia and Herzegovina in June 2008, and Kosovo in October 2015. Montenegro, Serbia, North Macedonia, and Albania are official EU membership candidate countries, while Bosnia and Herzegovina and Kosovo remain only potential candidate countries (EP, 2019). In 2019 EU prospects for 
triggering enlargement talks with Albania and North Macedonia were blocked. French President Emmanuel Macron, along with leaders in Denmark and the Netherlands, opposed and blocked the opening of membership talks with Albania and North Macedonia despite a recommendation from the European Commission and the European Parliament. This blockade caused a divide among EU leaders and resentment in Albania and North Macedonia. In March 2020 the EU blocked enlargement talks with both countries.

Kosovo presents a complex and multifaceted problem for the EU strategy in the Western Balkans (Beha \& Hajrullahu, 2020; Papadimitriou, Petrov $\&$ Greicevci, 2007). The Europeanisation of Kosovo compared to other Western Balkan countries differs due to the non-recognition of its statehood by five EU member states (Cyprus, Greece, Romania, Slovakia, and Spain). Thus political matters such as the non-recognition of Kosovo's statehood by five EU member states, as well as the limited Kosovan capacities to meet the Copenhagen criteria on political, legal, and economic matters, delay any substantial progress towards future EU membership of the country. In fact, the mechanisms for involving Kosovo in the EU integration processes despite to the non-recognition of its statehood by the EU itself presents a progressive effort (Hajrullahu, 2019). Kosovo remains the only European country in which the EU has legally experimented on how to relate to a state without treating it as independent and sovereign country (Elsuwege, 2017; Forum 2015).

By introducing new strategies for Kosovo's EU path, the EU has pushed the process forward through special considerations by existing EU structures. The EU's "sui generis" strategies for Kosovo compared to other countries (Palokaj \& Tuhina, 2016) are reflected in the invention of several mechanisms that have not been in place before. In November 2002 the EU introduced Stabilisation Tracking Mechanism (STM) as the mirror instrument of the Stabilisation and Association Process (SAP) for Kosovo. The STM was used to prepare the country for formal inclusion in the process when conditions would be met. ${ }^{4}$ Also, the joint declaration of the

4 Because Kosovo is under international administration and does not yet have a final status, it was unable to commence with SAP. To ensure that UNMIK and the Provisional Institutions of Self-Government (PISG) followed EU-compatible practices in the political, economic, and sectoral reform process, UNMIK and the European Commission agreed that an instrument was needed to monitor and drive the process. Although developments within Kosovo are not only a matter of reform, it was deemed beneficial for the PISG and UNMIK to follow the methodology and substance of the Stabilisation and Association Process and thus avoid isolation from the mainstream of European integration. 
Thessaloniki Summit, confirming the perspective of EU integration for all Western Balkan countries, contains specific standards for Kosovo related to the determination of Kosovo's status, which would open the way for the realisation of its European perspective (EU-Western Balkans Thessaloniki Summit, 2003). A European Future for Kosovo (EU, 2005) is another specific document for Kosovo's European perspective, which mentions Kosovo's full integration into the EU for the first time. A period of status negotiations facilitated by the UN Secretary General's special envoy, President Martti Ahtisaari, was followed by the EU High Representative Javier Solana's and the EU Commissioner for Enlargement Olli Rehn's joint report that envisioned a European perspective for Kosovo, the same as for the countries in the region (EU, 2007a).

In 2009 the EU upgraded the STM to a Political Dialogue of Stabilization-Association. With the publication of the European Commission's post-independence communication "Kosovo - fulfilling its European perspective" (EC, 2009) and the Feasibility Study for Kosovo (EC, 2012), SAA negotiations were concluded and the text of the agreement was agreed in October 2015. The SAA entered into force in April 2016 (SAA, 2015). The SAA marks the most significant step so far between the EU and Kosovo in legal terms, not only in the form of establishing contractual relations but also in economic, commercial, political, and other terms. Because it is an international agreement, the SAA defines mechanisms and official terms for the implementation of all reforms which will progressively align Kosovo with the EU in all policy areas, until the fulfilment of all EU standards. EU's internally disputed issue of Kosovo's statehood recognition has affected the scope and content of the SAA as well.

While Kosovo's SAA is similar to previous SAAs, it was signed by EU institutions and not by EU member states. Also, Kosovo's SAA is identified by an asterisk (*) after Kosovo's name. ${ }^{5}$ Indeed, the asterisk solution is an interesting modality to proceed with the development of EU-Kosovo relations in the short term but it is not tenable in the medium and long term (Elsuwege, 2017). However, concluding a bilateral agreement with a country with an asterisk is one thing, while accepting a potential member state with an asterisk is something completely different (Elsuwege, 2017). Also, the political promises in the SAA regarding Kosovo's full integration

5 The asterisk (*) is used after Kosovo's name, indicating that "this designation is without prejudice to positions on status, and is in line with UN Security Council Resolution $1244 / 1999$ and the International Court of Justice (ICJ) Opinion on the Kosovo declaration of independence". 
into the EU are vague and conditioned by "circumstances" (Palokaj \& Tuhina, 2016). The reservations regarding its international legal status have also led to different rules regarding the entry and residence of Kosovo nationals (Elsuwege, 2017).

Despite all the differences compared to other SAA agreements (Elsuwege, 2017), with the signing of the SAA Kosovo took on the responsibility of approximating the existing legislation. This means that existing laws and future legislation must be compatible with the EU acquis. Approximation at this early stage will focus on the internal market and the fields of freedom, security, and justice, as well as on trade-related areas (Republic of Kosovo, Government, 2014). An important issue is the translation of EU legislation as an integral part of the approximation of domestic legislation with the EU acquis. In March 2014 the Ministry of European Integration of the Republic of Kosovo and the Ministry of European Integration of the Republic of Albania signed a cooperation agreement on the translation of EU legislation into Albanian and cooperation on the approximation of legislation (Ministry of European Integration, 2014). While the need for proper approximation of (potential) candidate countries' existing legislation to that of the EU is evident, the implementation of the former in practice remains a key operative area of the SAA (Caka $\&$ Blockmans, 2009). European Commission reports on Kosovo state that it is at an early stage regarding alignment with European standards. Although legislative alignment has continued in some areas, implementation is weak (EC, 2018). However, some areas have made good progress, such as the free movement of goods, services, and capital; financial services; public procurement; competition; taxation; customs; statistics; and financial control (EC, 2018, pp. 3-5).

The lack of progress in harmonisation and implementation of the EU acquis in the public sector is due to Kosovo's weak internal capacities to meet its obligations and responsibilities on political, legal, and economic matters in the SAA. What follows is an analysis of the public administration reform (PAR) in Kosovo to exemplify the atypical transition of public administration and its role in the advancement of Kosovo's path toward EU membership. 


\section{Public Administration Reform and the Europeanisation Process in Kosovo}

For countries aspiring to join the EU, it is important to have fully developed and professional public administrations (Goetz, 2000; Lippert et al., 2001; Radaelli, 2000). In general, PAR presents the Western Balkan countries with significant hurdles. With that in mind, the EU is strengthening its support for public administration reform in the Western Balkan countries. In 2014 the European Commission launched the Enlargement Strategy and Main Challenges 2014-15 (EC, 2014). This refers to those seeking to join the EU and contains three pillars: rule of law, economic governance, and PAR. The emphasis is on drafting national strategies to improve public administrations at all levels. Adequate management of human resources; better policy planning, coordination, and development; sound administrative procedures; and improved public financial management, including revenue administration and collection are all of fundamental importance for the functioning of the state and for the implementation of reforms needed for EU integration (EC, 2014). Although there is no specific EU acquis chapter covering public administration, accession negotiations should be used to encourage the necessary reforms.

To strengthen its focus on PAR, the EC has outlined six key reform issues which represent the principles of public administration. These principles are set for countries aspiring to join the EU and currently receiving EU assistance through the IPA. Moreover, the EU acquis requirements, along with other EU guidelines and instructions, constitute the core principles in those areas where the EU acquis is in place (SIGMA, 2017). The principles explain what good governance involves and which requirements countries need to fulfil on their integration path. While these principles present useful guiding tools for Kosovo's aspiration to join the EU, in practice their implementation depends heavily on internal administrative capacities. Due to its atypical transition processes, it is noted here that Kosovo's public administration reform differs in many aspects from public administration reforms in other Western Balkan countries. Kosovo's public administration development and functioning has been characterised by a difficult legacy marked by systematic human rights violations and discriminations. After the 1999 war, in accordance with the UN Security Council Resolution 1244 (1999), UNMIK established the basis for the functioning of public administration (UNSCR 1244, 1999). The role of the UNMIK administration was to replace Serb and Yugoslav authorities in the territory of Kosovo and to assume full interim administrative responsibility (Yannis, 2004). 
During the UNMIK era, public administration in Kosovo was guided by the establishment of PISG, Provisional Institutions of Self-Government, (UNMIK Regulation 2001/9, 2001) as well as the launch of the Kosovo Standards Implementation Plan (Kosovo Standards Implementation Plan, 2003). The former document (UNMIK Regulation 2001/9, 2001) established the principles and the institutional set-up for the functioning of public administration, while the latter (Kosovo Standards Implementation Plan, 2003) set the standards that public institutions were required to meet as part of Kosovo's statehood building process. The exercise of public authority in all public institutions was through co-governance by international and local authorities (UNMIK Regulation No. 2000/1, 2000) ${ }^{6}$ and a step-by-step transfer of governing responsibilities from international to Kosovo authorities (Constitutional Framework in 2001).

Contrary to other countries in Eastern and Southern Europe that had begun political, economic, and administrative reforms in the 1990s, until 1999 Kosovo remained outside institutional reforms and professional capacity-building in public administration. Due to the so-called "special measures" introduced by Serbia and following the revocation of autonomy, roughly 90 per cent of Kosovo Albanian civil servants were expelled from public institutions (Batalli, 2012). This absence from work had a long-term negative impact on the capacities of civil servants: i.e., public administrations in the region had introduced new public management principles, such as digitalisation processes, much earlier. In Kosovo, the digitalisation of public administration is at an early stage of development (Muharremi, 2017).

The EU has contributed to all the phases of public administration development processes. In 2002 the European Agency for Reconstruction (EAR) administered the EU aid programme for Kosovo. The programme was divided into three parts: general reforms in public administration, reforms in health administration, and reforms in justice administration (Batalli, 2012). With the declaration of Kosovo's independence on February 17, 2008, competencies were delegated to Kosovo's local institutions. Since then, the overall management and functioning of Kosovo's public administration has been under the Ministry of Public Administration (MPA) and the Office of the Prime Minister.

6 With the aim of the development of a multiethnic, non-politicised, and efficient civil service for Kosovo, in May 2000 UNMIK established the Joint Interim Administrative Structures (JIAS), which were later replaced by the Provisional Institutions of Self-Government (PISG). JIAS created twenty administrative departments (akin to ministries) responsible for activities across sectors such as health, education, social welfare, public services, and the like. 
With the signing of the SAA, Kosovo committed itself to contributing to political, economic, and institutional stabilisation, as well as pursuing public administration reform. Under the SAA the Government of Kosovo undertook the obligation to ensure the development of a professional, efficient, and accountable public administration. Art. 120 of the SAA states that the cooperation between EU and Kosovo should focus on institution building, including the development and implementation of merit-based, transparent, and impartial recruitment procedures at both central and local levels, human resources management, and career development for the public service. It also ensures continued training and the promotion of ethics within the public administration (SAA, 2015, Art. 120). Education and training also play a particularly important role in the SAA. Based on Art. 107, Kosovo's institutions should aim to raise the level of general education and vocational education and training, as well as youth policy and youth work, as a means of promoting skills development, employability, social inclusion, and economic development in Kosovo. Moreover, Kosovo's government and the EU should cooperate to ensure that access to education at all levels and training is inclusive regardless of sex, racial or ethnic origin, religion or beliefs, disability, age, or sexual orientation (SAA, 2015, art. 107).

Since 2008, Support for Improvement in Governance and Management (SIGMA), a joint initiative between the Organisation for Economic Co-operation and Development (OECD) and the EU, has played a crucial role regarding PAR in Kosovo. SIGMA actively supports several institutions, including the following: the Office of the Prime Minister in the implementation of the new regulatory framework and practices for strategy planning, development, and monitoring for better co-ordinated and implemented sector strategies; the MPA in monitoring and reporting on the Public Administration Modernisation Strategy 2015-2020; the Ministry of Finance in strengthening the system of public internal financial control to promote implementation of the legal framework, and monitoring and reporting on the Public Finance Management Strategy for 2015-2020; the Procurement Review Body in increasing the efficiency of the public procurement remedies system and on assessing and adjusting the strategic framework for the development of the public procurement system (OECD/SIGMA, 2019). In general, the involvement of SIGMA has boosted the reform process, as Kosovo undertook several legal and strategic initiatives for a modern public administration (Shala, 2017).

At the present time, Kosovo's institutions are guided by four strategic planning documents regarding PAR: Strategy for Modernisation of Public Administration 2015-2020 (Ministry of Public Administration, 2015); Pub- 
lic Financial Management Reform Strategy 2016-2020 (Ministry of Finance, 2016); Strategy for Improving Policy Planning and Co-ordination in Kosovo 2017-2021 (Republic of Kosovo, 2016a); and Better Regulation Strategy 2.0 for Kosovo 2017-2021 (Republic of Kosovo, n.d.). These documents provide strategic guidance regarding the following three pillars of PAR: 1) development and coordination of policies and legislation - management of reforms under the direct responsibility of the Office of the Prime Minister; 2) civil service, public service delivery, and accountability, under the responsibility of the MPA; and 3) public finance management - under the responsibility of Ministry of Finance. The reform of civil service, public service delivery, and accountability (Pillar II) is managed by the MPA through the Strategy for Modernisation of Public Administration 2015-2020 that defines strategic objectives and policies for improving the functioning and modernisation of public administration, including the legal requirements for improving service delivery. The strategy is based on the context of Kosovo and experiences from other regional countries as a result of the EU enlargement process (Ministry of Public Administration, 2015).

Progress on the implementation of the strategies is monitored by the Council of Ministers for Public Administration Reform (CMPAR), the Coordination Group for the Modernisation of Public Administration, and the Department for the Management of Public Administration Reform as a monitoring mechanism established by the government (Republic of Kosovo, n.d.). The progress of PAR is regularly discussed by a PAR-Special Group comprising local and EU officials (EU-Kosovo 2013). It should be emphasized here that the Government of Kosovo and the European Commission started a high-level dialogue which culminated with the drafting of the European Reform Agenda (Republic of Kosovo, 2016b) to support and accelerate the implementation of the SAA. The ERA is a contractual relationship between the European Union (EU) and countries that are pursuing EU membership within the framework of the SAA implementation process. For Kosovo, the ERA was drafted with the aim of prioritising key reforms to be implemented by the end of 2017. Additionally, the government drafted the Economic Reform Programme (EC, 2019-2021) intended to be implemented in parallel. Both documents (ERA and ERP) serve as roadmaps for European integration. The ERA focuses on three main areas: good governance and the rule of law, competitiveness and investment climate, and employment and education (Republic of Kosovo, 2016b). These contain specific measures and objectives to be fulfilled in 2017, introduced in the Action Plan for the Implementation of Key Priorities. In assessing the efficiency and effectiveness (Group for Legal and 
Political Studies, GAP Institute \& Prishtina Institute for Political Studies, 2018) of institutions during the implementation process, the majority of objectives in the pillar addressing good governance and the rule of law were achieved. ${ }^{7}$ Regarding the pillar addressing competitiveness and investment climate, only a limited percentage of objectives was achieved. ${ }^{8}$ The least progress was made regarding the objectives of the employment and education pillar, which includes six main priorities focusing on improving employment conditions and opportunities specifically for women and younger generations and improving the quality of education through the implementation of new curricula, better teacher training programmes, and higher quality vocational training. ${ }^{9}$ The main problems in this area were related to the establishment and functioning of the Agency for the Curriculum, Standards and Assessment; improving the quality of Vocational Educational Training (VET); and reviewing study programmes and enrolment policies. In addition, the government did not undertake policies to foster links between higher education and the job market.

Notwithstanding the strategic documents, if public administration reform is to be successful, there is need for capable human resources with knowledge of the Europeanisation process and implementation capacities. Above all, PAR will be successful if it is led and implemented by professional experts independent of political influence (Mijalica, 2018). Governmental structures and strategic documents are not sufficient in achieving concrete results. Every year, the EC and SIGMA publish an assessment of Kosovo's progress and set forth their recommendations. The 2019 EC Report on Kosovo recognises that the country has achieved some overall progress such as the adoption of a package of laws on the functioning and organisation of public administration, on public officials, and on salaries

${ }^{7}$ Based on the monitoring of the ERA by the Group for Legal and Political Studies, this pillar has had the highest rate of achievement, even though it is considered to be one of the most challenging and problematic. More precisely, 68.6 per cent of the objectives have been achieved successfully, 20 per cent partially, and 11.4 per cent have not been achieved (Group for Legal and Political Studies, GAP Institute \& Prishtina Institute for Political Studies, 2018, p. 6).

${ }^{8}$ Monitoring results reveal that 32.9 per cent of the priorities were achieved by the end of 2017. On this note, 53.7 per cent were implemented partially, whereas 13.4 per cent were not fulfilled (Group for Legal and Political Studies, GAP Institute \& Prishtina Institute for Political Studies, 2018, p. 7).

9 The level of implementation of this pillar has been the lowest of all three. Specifically, by the end of 2017 only 21.9 per cent of the objectives were achieved, 59.4 per cent were implemented partially, and 18.7 per cent were not implemented at all (Group for Legal and Political Studies, GAP Institute \& Prishtina Institute for Political Studies, 2018, p. 7). 
(EC, 2019). New regulation has also been introduced regarding recruitment procedures for senior management positions in the civil service. Regarding service delivery, some progress has been made by introducing the 2017 Law on General Administrative Procedures (LGAP), which foresees training courses for public servants and has contributed to simplifying administrative procedures (Law No. 05/L-031, 2017).

The main recommendations in the European Commission's (EC) 2019 Report on Kosovo relate to the following areas: adoption of secondary legislation and effective implementation of the adopted laws; increase of accountability in the public sector by implementing the action plan on the rationalisation of agencies and creating a clear framework for managerial accountability and the delegation of responsibilities in public institutions; and improvement of legal predictability for citizens and businesses by gradually amending the identified special laws and implementing regulations that support the new LGAP and address the current backlog of administrative cases (EC, 2019). The SIGMA Monitoring Report 2019 focused on overseeing the area of service delivery as one of the relevant requirements of Kosovo's European integration pathway, as well as an important aspect of policy dialogue relating to the ERA, the SAA, and the EC's overall enlargement perspective (OECD/SIGMA 2019, p. 3). The SIGMA report recognises that some development has been achieved regarding the interoperability platform. Twelve public bodies and their information systems have been connected; the Government Gateway is now operational in technical terms but the quality of data in registries remains poor. Ex-ante processes for regulatory impact assessment have been strengthened through the improved guidance and training of public officials engaged in the development of concept documents and legislative initiatives. Still, harmonisation of special laws with the LGAP is slow; there are 231 laws and approximately 1000 by-laws with special administrative procedures that need to be adopted (OECD/SIGMA 2019, pp. 4-5). Key SIGMA report recommendations for the medium term (3-5 years) constitute: enhancement of customer feedback mechanisms; promotion of a customer-centred approach in public institutions and a more active role of the MPA; the government should reinforce central co-ordination, monitoring, and reviewing of government information communication technology (ICT) investments by introducing central business case reviews; the government should take measures to improve public service accessibility for people with disabilities (including through e-services); and a comprehensive system to monitor and evaluate the implementation of regulations concerning service accessibility for people with disabil- 
ities should be established by the Office of Prime Minister. The Office of Prime Minister should set up a comprehensive system to report the efforts of government bodies and municipalities to the public (OECD/SIGMA 2019, pp. 20-21). To implement the recommendations and address the lack of progress pointed out by the EC monitoring reports and SIGMA, renewed efforts should emphasize building the capacities of civil servants who need to implement the strategic goals foreseen in the strategic documents whose implementation is being measured. Drafting laws and establishing systems for better service delivery does constitute progress; however, implementation in practice requires professional expertise.

The Europeanisation process, including PAR, puts pressure on the relationship between the executive and legislative branches, with the emergence of a privileged accession team in the executive and the civil servant who must implement the changes, as well as in the relationship between central and municipal authorities. The team that leads the accession dialogue is usually composed of politicians, whereas in practice it is public servants rather than politicians who have had the longest and most consistent role in PAR. In addition, rapid changes of government and a high turnover of political appointments make the whole situation even more difficult. Therefore, further capacity-building of existing civil servants might not only ease the process of implementing the recommendations of monitoring bodies where reform progress is concerned, but could also enhance the overall implementation of reforms required by the European integration process. Undeniably, the education sector is key when it comes to long-term impact on all reform and integration processes. Capable professionals defined here as Europeanisation agents with appropriate skills, educational backgrounds, and work culture could offer a lasting perspective for successful reforms and accomplished processes. In view of this, we consider it important to analyse more closely the role of education in creating the necessary capacities for reforms and integration processes in Kosovo.

\section{The Role and Function of Education in the Europeanisation Process}

The education sector in Kosovo was not spared a difficult past. During the 1990s, it was subject to repression characterised by discrimination, segregation, violence against faculty staff and students, as well as destruction 
of infrastructure (Piciano \& Elbasani, 2019; Shahini, 2016). Even though educational facilities have been restored, the quality of education still suffers from the debilitating legacy of the 1990s (EC, 2017a). The education system fails to address the pedagogical and skills training needs of Europe's youngest population, resulting in vast numbers of unemployed youth without the skills or training required of a growing economy (USAID, 2014-2020). The University of Prishtina remains the biggest and oldest public higher education institution, although several other public universities have been established in recent years. The number of private higher education institutions is high in relation to the overall population (KAA, 2019). Because the new higher education institutions came about without adequate planning and support, they have not served education and capacity-building but a populist political agenda (Rexhaj \& Pupovci, 2015). The SAA, in art. 107, stipulates that Kosovan institutions should aim to raise the level of general education, vocational education and training, and youth policy and youth work as a means of promoting skills development, employability, social inclusion, and economic development in Kosovo. Moreover, the SAA points out that the Government of Kosovo and the EU should cooperate to ensure access to all levels of education and training, as well as freedom from discrimination on the grounds of sex, racial or ethnic origin, religion or beliefs, disability, age, or sexual orientation (SAA, 2015, Art.107). The relevance of the education sector in building the capacities required to undertake and implement the PAR has been highlighted by the EU. The 2012 Feasibility Study for the SAA noted that "in order to implement the reforms of the public administration, Kosovo needed to ensure sustainable public administration reform, an efficient and professional public administration; and to increase the share of persons belonging to minorities in the public administration" (EC, 2012). The conclusion of SAA negotiations between Kosovo and the EU and the positioning of Kosovo within a new context of European integration requires the building of new capacities that will cope with the European integration process, as well as the delivery of new services accessible to everybody, according to best international and European practices (Ministry of Public Administration, 2015). Also, the EC Report on Kosovo (2016a) reiterated its concerns regarding the non-merit-based recruitment process of civil servants and continued politicisation of public administration, the organisational fragmentation of the state administration, the absence of effective lines of accountability, the overlap of responsibilities of government agencies, the lack of professional human resource management due to politicisation and limited capacity, and the 
limited provision of training and opportunities for professional development available to all civil servants. ${ }^{10}$

In order to have a depoliticised, professional, inclusive, and effective public administration, capable of implementing EU legislation and managed in line with the best European practices in human resource management, there is a clear need for an education system that enables capacity-building. Thus, for a successful PAR, domestic Europeanisation and integration agents, able and willing to undertake and implement the transformative process, appear to be unavoidable. A quality student-centred education system is crucial in forming the capacities of domestic Europeanisation and integration agents. Kosovo participates in European mobility schemes such the Central European Exchange Programme for University Students (CEEPUS) and Erasmus Plus, and it benefits from various forms of bilateral and multilateral support. However, opportunities for staff and student mobility remain limited due to the issue of language and the visa regime (EC, 2017b).

To comply with the obligations outlined by the SAA in education specifically and PAR more generally, the EC has been providing funding and technical assistance since 2004 through the Young Cell Scheme (YCS) scholarship programme for master's degree studies at EU universities. The YCS scheme is being provided to assist Kosovo authorities in their efforts to build a professional, merit-based, accountable, and apolitical civil service at all levels of public administration. Upon the finalisation of their master's degree studies, YCS grantees are contractually obliged to return to Kosovo and work in Kosovan public administration for a minimum period of three consecutive years. Between 2004 and 2019 twelve cohorts of the YCS programme were organised.

The YCS programme is managed by the EU Office in Kosovo and is currently implemented by the British Council in Kosovo (ISIG, 2017). Students attending the programme are equipped with knowledge and expertise in key fields such as law, economics, and public administration. Out of approximately 260 students who have successfully completed the

10 The EC's 2016 Report on Kosovo states that: "In the coming year, Kosovo should in particular: review all independent bodies and start implementation of the recommendations of the review in order to enhance accountability, eliminate overlapping competencies and ensure a more streamlined public administration; [and] ensure that the planned legislative package covering civil service, salaries and organization of state administration is prepared in a coordinated way in an inclusive and evidence-based process on the basis of concept notes agreed at the government level" (p. 10). 
scholarship programme, roughly 85 per cent now work for the Government of Kosovo at various levels and public institutions, including ministries, such as the Ministry for European Integration, and independent authorities like the Central Bank (ISIG, 2017).

In assessing the impact of the ten-year legacy of the YCS programme on PAR in Kosovo overall, it has been stated that the programme has had a great positive impact on the country (ISIG, 2015, ISIG, 2017). This is due to forging individual capacities that support future civil servants in overcoming the existing challenges in the administration. YCS civil servants are generally perceived as non-political actors in the public administration environment. Moreover, YCS civil servants are strengthening the overall administrative system by capitalising on a shared vision of a public administration guided by EU principles (ISIG, 2017, p. 12). However, it should be noted that employment of YCS graduates in public institutions is facing challenges. Civil society organisations have demanded the resignation of the Minister for European Integration for not respecting the agreement with the EU in securing the jobs of YSC grantees in public administration and for not recognising the relevant role of the grantees in PAR (Shoqëria civile, 2019). Furthermore, the EU delegation in Kosovo has criticised Kosovo institutions for not respecting the 2012 IPA (Kadriu, 2019).

It is noted here that the initiation of PAR in Kosovo has not been accompanied by adequate academic education programmes. Almost all civil servants active in the 1990s left public service after 1999. The civil servants appointed after 1999 were either old civil servants from the 1980s, who had not been working for almost a decade due to Serbian repression, or new and inexperienced public servants employed by UNMIK without an adequate academic background. Due to the overall political situation and changes of authorities, Kosovo has not inherited a legacy of organisation and management. As a result, public sector entities are not systematically structured and managed. Relationships of authority and responsibility are not clearly defined and lines of communication are not established and maintained. This allows for flexibility but encourages $a d$ boc solutions and leads to certain individuals doing the bulk of the work, while many others contribute little or nothing. Also, the legal framework for all public sector entities, their management protocols, and their implementing powers are still in the process of being defined and elaborated.

Recently educated graduates with experience abroad are in short supply. They are also difficult to integrate into existing structures because (i) they lack concrete practical working experience and (ii) their ways of analysing 
problems and identifying solutions do not fit well with the existing organisational culture. Therefore, without proper professionalisation of its public administration, Kosovo continues to face difficulties implementing the EU acquis. That is why the role and qualities of the education system, higher education in particular, are of the utmost importance for PAR. The higher education system should have been equipped with much more specifically tailored education programmes such as Public Administration Management and European Studies to build the capacities of the current public administration staff. This would allow new people to take up positions and lead the processes, including Europeanisation and EU integration.

\section{Conclusions}

Improving the performance of public administration and achieving greater overall efficiency is of paramount importance in making sure Kosovo is aligned with international standards, thereby allowing it to fully enjoy the opportunities stemming from European integration. Thus PAR in Kosovo must remain a key priority on the public policy agenda. For Kosovo to comply with SAA obligations and achieve a successful PAR, much larger investments into and further development of the higher education sector is needed. An increase in the quality of studies and better opportunities for inclusion would enhance the employability and skills development of young generations. Indeed, the YCS has played a great role in preparing young professionals who could in the long term positively impact a transparent and professional public administration.

In future what is needed is a much stronger institutionalisation of placements of YCS and all other educational programme grantees by eliminating political interference from the process, as well as further utilisation of their capacities and potential in public administration. EU assistance in building up Europeanisation agents through international schemes such is the YCS is of great importance. However, for the Europeanisation process to be accomplished successfully, Kosovo's policymakers should undertake coherent and systematic measures to enhance the educational system as a key precondition to building the overall capacities for developing Europeanisation and EU integration agents. Decision- and policymakers should undertake twofold measures: (1) develop and implement policies that will cause substantial positive impact in institutional transformations of the higher education sector and its relationship with public institutions, and (2) enhance existing and develop new selected academic 
and training programmes in all public and private education institutions. In introducing and implementing those measures, Kosovo's authorities will develop Europeanisation and EU integration agents to a much greater extent than before, while at the same time they will meet reform criteria related to the education sector as foreseen in the SAA.

It should be noted that the goal of PAR goes beyond Europeanisation and EU integration. PAR and other reforms contribute to breaking up with the discriminatory public administration that was the result of a violent past. PAR directly impacts the well-being of citizens, enabling an overall contribution to the building and maintaining of a long-lasting culture of peace as one of the key aims of Europeanisation and EU integration processes. It is important that both at home and abroad the big picture is seen by recognising education as one of the most important ways to achieve effective and efficient Europeanisation and EU integration of Kosovo and the whole Western Balkan region.

To conclude, it is evident that the legacy of an atypical transition, developments related to the 1998/9 war and its aftermath, and the transition from international to local governance continues to affect Kosovo's structural consolidation (constitution, state organisation) and the level of representative consolidation (parties, associations), followed as it is by a sluggish process of civil-cultural transformation. Without a fully consolidated and crisis-resistant democracy, neither the initiated PAR based on the values of good governance, transparency, and accountability within a system based on the rule of law, nor the "fair and just" distribution of resources in society have a perspective. A successful PAR accompanied by complementary measures, such as a better educational system at all levels, will further affect the processes for embracing EU's standards and values and incorporating them into everyday practice. The need for Europeanisation and EU integration agents in Kosovo is even greater than in other countries with less atypical transition processes in the region and beyond.

\section{References}

Anastasakis, O. (2005). The Europeanization of the Balkans. Brown Journal of World Affairs, 12(1), 77-89.

Bache, I., \& Marshall, A. (2004). Europeanisation and domestic change: A governance approach to institutional adaptation in Britain. Queen's Papers on Europeanisation, 5, 1-17. 
Bandov, G., \& Kolman, H. N. (2018). Research on Europeanization in literature: From the top-down approach to Europeanization as a multi-directional process. CADMUS, 3(5), 134-144.

Batalli, M. (2012). Reforma e administratës publike në Kosovë [Public administration reform in Kosovo], Thesis, 1(2012), 5-26. Retrieved from https://www. academia.edu/17007284/01_2012_sq_03_OTDqa

Beha, A., \& Hajrullahu, A. (2020). Soft competitive authoritarianism and negative stability in Kosovo: Statebuilding from UNMIK to EULEX and beyond. Southeast European and Black Sea Studies 20(1), 103-122, https://doi.org/10.1 080/14683857.2019.1709686

Börzel, T. A. (2011). When Europeanization bits limited statehood: The Western Balkans as a test case for the transformative power of Europe (KFG Working Paper), 30(1), 1-19. Retrieved from http://userpage.fu-berlin.de/kfgeu/kfgwp/ wpseries/WorkingPaperKFG_30.pdf

Bulmer, S. (2007). Theorizing Europeanization. In P. Graziano, \& M. P. Vink (Eds.), Europeanization: New research agendas (pp. 46-58). Basingstoke, United Kingdom: Palgrave Macmillan.

Caka, F., \& Blockmans, S. (2009). Implementing the stabilisation and association agreement in Albania: Avoiding discriminatory practices in the free movement of goods. European Journal of Law Reform, 11(4), 511-530.

Casper, G. (1995). Fragile democracies: The legacies of authoritarian rule. Pittsburgh, USA: University of Pittsburgh Press.

Elsuwege, P. V. (2017). Legal creativity in EU external relations: The stabilization and association agreement between the EU and Kosovo. European Foreign Affairs Review, 22(3), 393-410.

Goetz, K. H. (2000). European integration and national executives: A cause in search of an effect? West European Politics, 23(4), 211-231, https://doi. org/10.1080/01402380008425406

Goetz, K. H. (2001). Making sense of post-communist central administration: Modernisation, Europeanisation or Latinisation? Journal of European Public Policy, 8(6), 1032-51.

Grabbe, H. (2011). How does Europeanization affect CEE governance? Conditionality, diffusion and diversity. Journal of European Public Policy, 8(6), 1013-1031, https://doi.org/10.1080/13501760110098323

Hajrullahu, A. (2019). The Serbia Kosovo dispute and the European integration perspective. European Foreign Affairs Review, 24(1), 101-120.

Hirschhausen, V. U., \& Patel, K. K. (2010). Europeanization in history: An introduction. In M. Conway \& Patel K. K. (Eds.), Europeanization in the twentieth century: Historical approaches (pp. 1-18). Basingstoke, United Kingdom: Palgrave Macmillan, https://doi.org/10.1057/9780230293120_1

Howell, K. (2002). Developing conceptualizations of Europeanization and European integration: Mixing methodologies. ESRC Seminar Series / UACES Study Group on the Europeanization of British Politics, 1, 1-27. Retrieved from http:// aei.pitt.edu/1720/1/Howell.pdf 
Lippert, B., Umbach, G., \& Wessels, W. (2001). Europeanization of Central and Eastern European executives: EU membership negotiations as a shaping power. Journal of European Public Policy, 8(6), 980-1012, https://doi. org/10.1080/13501760110098314

Merkel, W. (1995a). Transformationsstrategien, Probleme, Erfahrungen und Grenzen [Transformation strategies, problems, experiences and limits]. Internationale Politik, 6(50), 3-8.

Merkel, W. (1995b). Theorien der Transformation: Die demokratische Konsolidierung postautoritärer Gesellschaften [Theories of transformation: The democratic consolidation of post-authoritarian societies]. In K. von Beyme \& C. Offe (Eds.), Politische Theorien in der Ära der Transformation [Political theories in the era of transformation] (pp. 30-58). Opladen, Germany: Westdeutscher Verlag, https://doi.org/10.1007/978-3-322-86620-2_2

Mijalica, L. (2018, March 21-23). Kosovo's public administration reform in the context of the European Union membership process. [Conference proceedings]. 11 $1^{\text {th }}$ International Conference on Education, Humanities, Social Sciences and Management (EHSSM-18), Istanbul, Turkey. Retrieved from http://dirpub. org/images/proceedings_pdf/DIR0318031.pdf, https://doi.org/10.17758/ dirpub1.dir0318031

Muharremi, R. (2017). The challenge of introducing new public management. Croatian and Comparative Public Administration, 17(1), 7-28.

Offe, C. (1994). Der Tunnel am Ende des Lichts: Erkundungen der politischen Transformation im Neuen Osten [The tunnel at the end of the light: Explorations of political transformation in the New East]. Frankfurt, Germany: Campus, https://doi.org/10.1177/095892879500500406

Olsen, P. J. (2020). The many faces of Europeanization. JCMS Journal of Common Market Studies. 40(5), 921-952, https://doi.org/10.1111/1468-5965.00403

Palokaj, A., \& Tuhina, G. (2016). The upshot of the SAA: Kosovo-EU relations. [Research paper]. Retrieved from http://kfos.org/wp-content/uploads/2016/11/ MSA-ENG_TEXT-2.compressed.pdf, https://doi.org/10.18411/d-2016-154

Papadimitriou, D., Petrov, P., \& Greicevci, L. (2007). To build a state: Europeanisation, EU actorness and state-building in Kosovo. European Foreign Affairs Review, 12(2), 219-238.

Parrott, B. (1997). Perspectives on postcommunist democratization. In K. Dawisha \& B. Parrott (Eds.), Politics, power, and the struggle for democracy in SouthEast Europe (pp. 1-39). Cambridge, United Kingdom: Cambridge University Press, https://doi.org/10.1017/cbo9780511559228.002

Petritsch, W., \& Solioz, C. (2012). Trade union weakness and the political role of union in South-East Europe: Europeanisation at the crossroads. Journal for Labour and Social Affairs in Eastern Europe, 15(3), 413-420, https://doi. org/10.5771/1435-2869-2012-3-413

Radaelli, C. M. (2000). Whither Europeanization? Concept stretching and substantive change. European Integration Online Papers, 4(8), 1-25. 
Radaelli, C. M. (2003). The Europeanization of public policy. In K. Featherstone \& C. Radaelli (Eds.), The politics of Europeanization (pp. 27-56). Oxford, United Kingdom: Oxford University Press, https://doi.org/10.1093/0199252092.003.0002

Rexhaj, X., \& Pupovci, D. (2015). Access to higher education in Kosovo. Academia, North America, 5(1), 103-134.

Risse, T., Cowles, M. G., \& Caporaso, J. (2001). Europeanization and domestic change: Introduction. In M. G. Cowles, J. Caporaso \& T. Risse (Eds.), Transforming Europe: Europeanization and domestic change (pp. 1-20). Ithaca, NY: Cornell University Press, https://doi.org/10.7591/9781501723575-002

Sartori, G. (1997). Demokratietheorien [Theories of democracy]. Darmstadt, Germany: Primus-Verlag.

Shala, F. (2017, June). Europeanization of Kosovo's public administration: 20092017. [Thesis dissertation, Utrecht University]. Retrieved from https:// is.muni.cz/th/wt95x/Florin_Shala.pdf

Shoqëria civile: Vendimet e kundërligjshme të ministres Hoxha, rrezikojnë të ardhmen e të rinjve

Kosovar [Civil society: Illegal decisions of Minister Hoxha endanger the future of Kosovar youth]. (2019, August 8). Telegrafi. Retrieved from https://telegrafi. $\mathrm{com} /$ shoqeria-civile-vendimet-e-kunderligjshme-te-ministres-hoxha-rrezikojne-te-ardhmen-e-te-rinjve-kosovar/

Uvalic, M. (2009, June 25-27). EU policies towards the Western Balkans: The role of sticks and carrots. [Conference proceedings]. AISSEC Conference, Perugia, Italy. Retrieved from https://www.academia.edu/26101793/EU_policies_towards_the_Western_Balkans_The_role_of_sticks_and_carrots, https://doi. org/10.1007/978-3-319-91412-1_10

Uvalic, M. (2010). Integrating the Western Balkans into the European Union: How useful are the EU economic accession criteria? In B. Cerović \& M. Uvalić (Eds.), Western Balkans' accession to the European Union: Political and economic challenges (pp. 53-86). Beograd, Serbia: Cugura Print, https://doi. org/10.1007/978-3-319-91412-1_10

Yannis, A. (2004). The UN as government in Kosovo: The politics of international administration. Journal of Global Governance, 10(1), 67-81.

\section{Legal Sources}

Kosovo Standards Implementation Plan (KSIP). Retrieved from http://operationkosovo.kentlaw.edu/symposium/resources/KSIP\%20final\%20draft\%2031\%20 March\%202004b.htm

Law No. 05/L-031, 2017 On General Administrative Procedure. Retrieved from http://www.mei-ks.net/repository/docs/annex_9_law_on_general_administrative_procedure.pdf

European Union (2007b). Treaty of Lisbon amending the Treaty on European Union and the Treaty establishing the European Community (OJ C 306, 17.12.2007), https://doi.org/10.1163/2211-4394_rwilwo_com_031431 
UNMIK Regulation No. 2000/1 on Joint Interim Administrative Structure (JIAS), 14 January 2000. Retrieved from https://unmik.unmissions.org/sites/default/ files/regulations/02english/E2000regs/RE2000_01.htm

UNMIK Regulation No. 2001/9, Constitutional Framework for Provisional Selfgovernment in Kosovo, May 15, 2001. Retrieved from https://unmik.unmissions.org/sites/default/files/regulations/02english/E2001regs/RE2001_09.pdf

UNSCR (1999). United Nations Security Council, Resolution 1244 (S/Res/1244), Security Council, Distr.: General, 10 June. Retrieved from https://digitallibrary.un.org/record/274488? $\ln =\mathrm{en}$

\section{Strategic and policy documents}

Council of the European Union, Stabilization and association agreement between the European Union and Kosovo (2 October). Retrieved from http://data.consilium.europa.eu/doc/document/ST-10728-2015-REV-1/en/pdf

European Commission (2004). Report from the Commission: The stabilization and association process for South East Europe (Third Annual Report). Retrieved from https://eur-lex.europa.eu/LexUriServ/LexUriServ.do?uri=COM\%3A20 04\%3A0202\%3AFIN\%3AEN\%3APDF

European Commission (2009). Communication from the Commission to the European Parliament and the Council: Kosovo fulfilling its European perspective. Retrieved from https://ec.europa.eu/neighbourhood-enlargement/sites/near/files/kosovo_ study_en.pdf

European Commission (2012). Communication from the Commission to the European Parliament and the Council on a feasibility study for a stabilization and association agreement between the European Union and Kosovo. Retrieved from https:// ec.europa.eu/neighbourhood-enlargement/sites/near/files/pdf/key_documents/2012/package/ks_feasibility_2012_en.pdf, https://doi.org/10.1163/22107975_hrd-4679-0058

European Commission (2014). European Commission: Enlargement strategy and main challenges 2014-15: Communication from the Commission to the European Parliament, the Council, the European Economic and Social Committee and the Committee of the Regions. Retrieved from https://www.ab.gov.tr/files/000etkinlikler/2014 enlargement_strategy_paper.pdf, https://doi.org/10.1080/13880290902938435

European Commission (2016a). Commission staff working document Kosovo. Retrieved from https://ec.europa.eu/neighbourhood-enlargement/sites/near/files/ pdf/key_documents/2016/20161109_report_kosovo.pdf

European Commission (2016b). European neighbourbood policy and enlargement negotiations: Accession criteria. Retrieved from https://ec.europa.eu/neighbourhood-enlargement/policy/glossary/terms/accession-criteria_en

European Commission, Education, audiovisual and culture executive agency (EACEA) (2017a). Overview of the bigher education system. Retrieved from https:// eacea.ec.europa.eu/sites/eacea-site/files/countryfiche_kosovo_2017.pdf 
European Commission (2017b). Erasmus + for bigher education in Kosovo. Retrieved from https://ec.europa.eu/assets/eac/erasmus-plus/factsheets/neighbourhood/ erasmusplus_kosovo_2017.pdf

European Commission (2018). Communication from the Commission to the European Parliament, the Council, the European Economic and Social Committee and the Committee of the Regions: A credible enlargement perspective for and enhanced EU engagement with the Western Balkans. Retrieved from https://ec.europa.eu/ commission/sites/beta-political/files/communication-credible-enlargementperspective-western-balkans_en.pdf .

European Commission (2019-2021). Commission staff working document: Economic reform programme of Kosovo Commission Assessment. Retrieved from https://ec.europa. eu/neighbourhood-enlargement/sites/near/files/kosovo_2019-2021_erp.pdf

European Commission (2019). Commission Staff Working Document Kosovo* 2019 Report. Retrieved from https://ec.europa.eu/neighbourhood-enlargement/sites/near/files/20190529-kosovo-report.pdf

EU-Western Balkans Thessaloniki Summit (2003). Declaration. Retrieved from https://ec.europa.eu/commission/presscorner/detail/en/PRES_03_163

European Union (2005). A European future for Kosovo: Communication. Retrieved from https://ec.europa.eu/commission/presscorner/detail/en/IP_05_450

European Union (2007a). European Commission Joint report by Javier Solana, EU bigh representative for the CFSP and Olli Rebn, EU commissioner for enlargement, on the state of preparations of the future EU and international presence in Kosovo. Retrieved from https:/www.consilium.europa.eu/ueDocs/cms_Data/docs/ pressData/en/reports/93377.pdf

EU - Kosovo (2013). The joint agreed EU-Kosovo conclusions of the public administration reform, Special group, beld on $26^{\text {th }}$ April. Retrieved from https://eeas. europa.eu/delegations/kosovo_en/44545/Kosovo's\%20progress\%20on\%20 Public\%20Administration\%20Reform

Finnish Presidency and the EC (1999). Report to the European Council on EU action in support of the Stability pact and South Eastern Europe. Retrieved from https://www.europarl.europa.eu/summits/hel1_en.htm

Group for Legal and Political Studies, GAP Institute \& Prishtina Institute for Political Studies (2018). European Reform Agenda (ERA): High level dialogue between Kosovo and the European Union [ERA Monitoring Report JanuaryJune 2018]. Retrieved from http://www.eramonitoring.org/wp-content/uploads/2019/06/Monitoring-Report-for-January-June-2018.pdf

Ministry of European Integration (2014). Translated legal acts of EU legislation. Retrieved from http://www.mei-ks.net/en/translated-legal-acts-of-eu-legislationand http://mei-ks.net/en/translation-of-acquis-563

Ministry of Finance (2016). Public finance management reform strategy (PFMRS) of Kosovo 2016-2020. Retrieved from http://www.kryeministri-ks.net/repository/ docs/Public_Finance_Management_Reform_Strategy2016-2020.pdf

Ministry of Public Administration (2015). Strategy on modernization of public administration 2015-2020. Retrieved from https://map.rks-gov.net/page.aspx?id=2,31 
OECD/SIGMA (2019). Monitoring report: The principles of public administration. Retrieved from http://www.sigmaweb.org/publications/Monitoring-Report2019-Kosovo.pdf

Republic of Kosovo, Government (2014). Practical guidelines for legal approximation of the legislation of the Republic of Kosovo with the legislation of the European Union Retrieved from http://mei-ks.net/repository/docs/practical_guidelines_ for_legal_aproximation.pdf

Republic of Kosovo (n.d.). Better Regulation Strategy 2.0 for Kosovo, 2017-2021. Retrieved from http://www.kryeministri-ks.net/repository/docs/Better_Regulation_Strategy_2_0_for_Kosovo_-_ENGLISH.pdf

Republic of Kosovo (2016a). Strategy for improving policy planning and coordination in Kosovo (integrated planning system) 2017-2021. Retrieved from http://www. kryeministri-ks.net/repository/docs/Strategy_for_Improving_Policy_Planning_and_Coordination_in_Kosovo_2017-2021.pdf

Republic of Kosovo Government of Kosovo. (2018). Final report on implementation of the European reform agenda (ERA) 2016-2018. Retrieved from https:// www.mei-ks.net/repository/docs/raporti_mbi_zbatimin_e_era_1_11_2016_30_11_2018_final_eng.PDF

Republic of Kosovo (2016). European reform agenda (ERA) Kosovo-EU bigh level dialogue on key priorities. Prishtina. Retrieved from https://www.mei-ks.net/repository/docs/era_final.pdf(2015).

SIGMA (2017). Principles of public administration. Retrieved from http://www.sigmaweb.org/publications/Principles-of-Public-Administration_Edition-2017_ ENG.pdf

Stability Pact for South Eastern Europe. (1999). Stability Pact for South Eastern Europe, Declaration. Retrieved from http://www.g8.utoronto.ca/summit/1999koln/ pact.htm

Unite State Agency International Development (USAID) (2014-2020). Kosovo: Country development cooperation strategy. Retrieved from https:/www.usaid. gov/sites/default/files/documents/1863/CDCS_Kosovo_Dec_2020.pdf

\section{Blogs and other online sources}

European Parliament (EP) (2019). The Western Balkans [Fact sheet]. Retrieved from https://www.europarl.europa.eu/factsheets/en/sheet/168/the-western-balkans

Forum 2015 (2013). Kosovo-EU relations: The history of unfulfilled aspirations? Lost opportunities in Kosovo's European integration process [Short analysis of public policies] Retrieved from http://kfos.org/wp-content/uploads/2013/04/KosovoEU-Relations-The-History-of-Unfulfilled-Aspirations.pdf

Institute of International Sociology of Gorizia (ISIG) (2015). Higher education for public administration reform in Kosovo [Final report]. Retrieved from https:// ycskosovo.eu/wp-content/uploads/2015/11/YCS_Expert-Study.pdf 
Institute of International Sociology of Gorizia (ISIG) (2017). Expert study. Young cell scheme round X: Assessment [Expert Study]. Retrieved from https://ycskosovo.eu/wp-content/uploads/2018/01/YCS_ExpertStudy_ISIG_2017-1.pdf

Kosovo Accreditation Agency (KAA). (2019). Kosovo bigher education institutions [Report] Retrieved from http://www.akreditimi-ks.org/new/index.php/en/ download/higher-eduacion-institutions

Kadriu, K. (2019, August 7). BE-ja kritikon ministren e Integrimeve për shkak të tentimit për t'i zënë vendet e bursistëve [The EU criticizes the Minister of Integration for trying to take the place of scholarship holders] KOHA net [Online article]. Retrieved from https://www.koha.net/arberi/177971/be-ja-kritikon-ministrene-integrimeve-per-shkak-te-tentimit-per-ti-zene-vendet-e-bursisteve/

Piciano, N., \& Elbasani, A. (2019, March 28). UN shares blame for segregated education in Kosovo. Balkan Insight [Online article]. Retrieved from https:// balkaninsight.com/2019/03/28/un-shares-blame-for-segregated-education-inkosovo/

Shahini, B. (2016, October 14). Lessons in resistance: Kosovo's parallel education system. Prishtina Insights [Article]. Retrieved from https://prishtinainsight.com/ lessons-resistance-kosovos-parallel-education-system-1990s-mag/

Vogel, T. (2018, October 9). Out of focus: The EU's relations with the Western Balkans. Heinrich Böll Stiftung [Online article]. Retrieved from https:// eu.boell.org/en/2018/10/09/out-focus-eus-relations-western-balkans 


\title{
PUBLIC ADMINISTRATION IN AN ATYPICAL TRANSITION AND THE NEED FOR THE AGENTS OF EUROPEANISATION IN KOSOVO
}

\begin{abstract}
Summary
This article investigates public administration reform in Kosovo by: a) analysing the extent to which an atypical transition affects administrative and governance reforms, b) examining the Europeanisation process and efforts to barmonise legislation with the European Union's acquis communautaire as the main driving force towards a successful transition, and c) reiterating the relevance and function of the educational system in the Europeanisation process. The article addresses the following question: can the Europeanisation process be accomplished successfully when the educational system, which is limited in scale, does not manage to generate a sufficient number of Europeanisation agents? In post1999 Kosovo, public administration has been undergoing continuous reforms to detach itself from the discriminatory legacy of communist and Serbian rule, to transfer authorities from internationally established bodies to local ones, to enbance capacity-building through international assistance, and to move forward with further reforms as part of Kosovo's EU integration efforts. Public administration reforms remain affected by past legacies, namely the atypical transition characterised by a post-WWII communist dictatorship, the Serbian apartheid-like discrimination in the 1990s, an UN-led interim administration, and challenges of capacity-building. The article concludes that without a fully consolidated and crisis-resistant democracy neither the initiated public administration reform based on the values of good governance, nor the "fair and just" distribution of resources in society have a perspective. For instance, to comply successfully with the public administration reform obligations set out in the EU's Stabilisation and Association Agreement, Kosovo needs greater capacities and professionals serving as Europeanisation agents. As a result, much larger investments in education, research, and development appear to be paramount. An increase in the quality of education and study capacities, as well as better opportunities for social inclusion would improve the performance of public administration and enbance good governance.

Keywords: Europeanisation, European Union, Kosovo, public administration, education, Europeanisation agents
\end{abstract}




\section{JAVNA UPRAVA U KONTEKSTU ATIPIČNE TRANZICIJE I POTREBA ZA AGENTIMA EUROPEIZACIJE}

\section{Sažetak}

Reforma javne uprave na Kosovu ispituje se kroz: a) analizu mjere do koje atipična tranzicija utječe na reforme javne uprave $i$ upravljanja, b) razmatranje procesa europeizacije $i$ usklađivanja zakonodavstva sa zajedničkom pravnom stečevinom Europske unije kao glavnim snagama uspješne tranzicije te c) naglašavanje važnosti $i$ uloge obrazovnog sustava u procesu europeizacije. Ključno je pitanje može li proces europeizacije biti uspješan ako obrazovni sustav, koji je ograničenog kapaciteta, ne uspijeva stvoriti dovoljan broj agenata europeizacije. Kosovska je javna uprava prolazila stalne reforme poslije 1999. kako bi se udaljila od nasljeđa socijalizma i srpske vladavine, preuzela ovlasti s medunarodno osnovanib tijela na domaća, ojačala kapacitete kroz međunarodnu pomoć $i$ nastavila reforme u sklopu europske integracije Kosova. Reforme javne uprave $i$ dalje su pod utjecajem prijašnjeg nasljeđa $i$ atipične tranzicije što uključuje socijalizam poslije II. svjetskog rata, diskriminaciju Srbije koja podsjeća na aparthejd tijekom 1990-ib, privremenu upravu Ujedinjenib naroda $i$ probleme s jačanjem kapaciteta. Zaključuje se da bez konsolidirane demokracije otporne na krize ni započeta upravna reforma na vrijednostima dobroga upravljanja ni »pravedna $i$ pravična « raspodjela sredstava $u$ društvu nemaju perspektive. Kako bi, primjerice, Kosovo moglo poštivati obveze oko reforme javne uprave iz Sporazuma o stabilizaciji i pridruživanju Europskoj uniji, potrebni su snažniji upravni kapaciteti i veći broj profesionalnog osoblja koje bi služilo europeizaciji. Zato su potrebna mnogo veća ulaganja u obrazovanje, istraživanje i razvoj. Unaprjeđenje kvalitete obrazovanja i studijskib kapaciteta te bolje prilike za socijalnu uključenost unaprijedili bi uspješnost javne uprave $i$ osigurali dobro upravljanje.

Ključne riječi: europeizacija, Europska unija, Kosovo, javna uprava, obrazovanje, agenti europeizacije 